DOI 10.4467/2543733XSSB.21.016.13809

\title{
BILATERAL RELATIONS WITH THE REPUBLIC OF /NORTH/ MACEDONIA AS AN ELEMENT OF BULGARIAN REGIONAL POLICY AFTER 1989
}

\begin{abstract}
Summary
The article begins with a re-evaluation of the often neglected importance of 1989 developments in Skopje that inaugurated the subsequent transition of Yugoslav Macedonia leading to its transformation into an independent republic. The text argues that the outcome of the often overlooked congress of the League of Communists of Macedonia in late November 1989 dismantled a small break out of the pan-European Berlin Wall that autumn.

After 1989 Bulgaria maintained a policy aimed at limiting and the non-proliferation of the conflict from the dissolving Yugoslav federation and contributed to the stabilization of the former Yugoslav and wider region. One of the most sensitive aspects of Sofia's regional policy was that towards Skopje. The article offers evidence and argues that Bulgaria's approach since 1989 went through different phases but nonetheless was based on three key constant principles: first, support for the independence and for the statehood of the new Republic of Macedonia; second, the countering and dismantling of Macedonianism (in its 'Yugoslav' and 'antiquated' versions alike) both as a provocative construct of history and as Skopje's foreign policy practice; third, seeking of solutions within the wider EU and NATO framework and support for the Republic of /North/ Macedonia's integration into NATO and EU structures.
\end{abstract}

Keywords: North Macedonia, EU integration, Bulgaria, Bulgarian Foreign Policy, Macedonianism

The autumn of 1989 brought about stark changes in Bulgaria and low-key ones in the Socialist Republic of Macedonia (SRM), the southernmost part of federal Yugoslavia. The importance of the year 1989 for Bulgaria is universally acknowledged. The symbolic fall of the 'Berlin wall' in Sofia followed a day after the collapse of the original wall - on November 10, 1989 the longtime communist leader Todor Zhivkov was forced to resign publicly. Technically this was an internal coup within the ruling Bulgarian Communist 
Party with the decisive influence and guidance from Moscow ${ }^{1}$. For the majority of the Bulgarians, however, the name of Todor Zhivkov was a synonym of one-party communist rule, and nothing could continue as before. We have already marked the 30th anniversary of the start of the transition to multi-party democracy.

Quite more overlooked is the importance of 1989 for the development of Yugoslav Macedonia. Indeed, as we know, the transformation and ultimate dissolution of the federation took place somewhat later, the focal starting point being the break-up of the League of Communists of Yugoslavia at its $14^{\text {th }}$ Congress in January 1990.

However, 1989 was an important year in the Yugoslav Macedonian evolution that led to the ultimate independence. In the crucial month of November 1989 the regular Tenth Congress of the ruling party, the League of Communists of Macedonia (LCM), was scheduled. This forum entrusted the power to the young Slovenian-trained activist Petar Goshev who was not only reform-minded but also independent from Slobodan Milošević and Belgrade. In 1989 and especially in the months leading to the congress in November 1989 preparations were made by the Milošević regime to stage a coup in Skopje similar to the so-called 'antibureaucratic revolutions' in Novi Sad, Titograd (Podgorica) and Pristina. An operation was devised, nominally led by obscure Kossovo Serb figures, with crucial street demonstrations planned to be staged in Skopje in the days leading to the congress. Yet the SRM's leadership had the courage to resist the pressure and warned Belgrade that it will openly oppose meddling from the North ${ }^{2}$. At that time, in late November 1989 the Milošević regime was in a heated dispute not only with suppressed Kosovo Albanians, but with Slovenia as well. The preparations were in full swing for the planned huge demonstration in Ljubljana on December 1, 1989 with the possible aim to destabilize the Slovenian leadership. The people around Milošević probably calculated that it would be counterproductive to open a new front to the south and therefore cancelled the plan for open disruption of SRM's power structures.

This congress of the LCM was important not only in terms of leadership elections - in addition to the success of the reform-minded faction it voted for the acceptance of the 'political pluralism's, an euphemism for the controlled multi-party system. Precisely as a result of that decision, a number of various political parties were established in the Socialist Republic of Macedonia during the first half of 1990 and in the following months ${ }^{4}$. The congress decision was legally implemented by the vote of the Sobranie of the SRM on April 12,1990 that permitted and regulated the establishment of political parties ${ }^{5}$. On September 20 the same body voted for a drastic change of the Constitution of the SRM - streamlining

\footnotetext{
${ }^{1}$ Among the voluminous literature on the 10 November 1989 in Bulgaria diaries-memories of the deputy prime minister and candidate-member of Politbureau at the time stand out as insider evidence of the events: Г. Йорданов, Притаени мигове. Книга втора. Откровения. София: Издателство „Захарий Стоянов”, 2017, c. 141.

${ }^{2}$ С. Орданоски. Пресудни години: разговор со д-р Јаков Лазароски. Скопје: Култура, 2013, с. 62-63. The Tenth congress of LCM was held on 25-27 November 2020.

${ }^{3}$ С. Орданоски. Пресудни години ..., с. 101-104.

${ }^{4}$ Useful handbook on the political parties, established in the proceess of transformation of Yugoslav Macedonia into independent Republic of Macedonia: Ц. Мојаноски. Летопис на македонската демократија. Скопје: Пакунг, 2013.

5 Закон за изменување и дополнување на Законот за општествените организации и здруженијата на граѓани, „Службен весник на СРМ”, 13.04.1990, с. 237-239; Ал. Спасеноски. Еволуција на македонскиот партиски систем от монизам кон плурализам, Политичка мисла, бр. 58, декември 2019, с. 29-30.
} 
the complicated multi-chamber parliament into a single 120-member body, establishing the institutions of government (vlada) and of the president and vice-president, all elected by the parliament. Sobranie also adopted laws on future general elections at the same session $^{6}$. Thus the path to radical political transformation of the state was legally open.

Due to different internal and mainly external factors the initially envisaged controlled party system quickly developed into a full-fledged multi-party one - a process that is beyond the scope of this text. Ultimately the LCM congress' decisions inaugurated the gradual emergence of the multi-party system in Yugoslav Macedonia that in its own term contributed to the formal independence of the Republic of Macedonia (RM). November 1989 started the important mutually connected chain of events that included the multi-party elections at the end of the following year, the Declaration of Sovereignty of the SRM issued by the parliament on January 25, 1991, the Referendum on Sovereignty of September 8, 1991 and the letters of December 2, 1991 asking for international recognition of independence forwarded by the president and foreign minister of $\mathrm{RM}^{7}$. Otherwise the destiny of Vardar Macedonia might have been within the firmer grasp of Slobodan Milošević, similar to that of Montenegro, or even Vojvodina.

The Velvet revolution of 1989 led to the independence of the Bulgarian foreign policy that soon had to face challenges of the impending Yugoslav dissolution crisis. Sofia maintained a policy aimed at limiting and non-proliferation of the conflict and contributed overall to the stabilization of the former Yugoslav and wider region. This text is focused on one of the most sensitive aspects of Sofia's regional policy - that towards Skopje, and provides evidence that Bulgaria's approach since 1989 went through different phases but nonetheless was based on three constant principles.

\section{Support for the independence and for the statehood of the new Republic of Macedonia.}

During the initial formative period of quick changes in 1990-1992 Bulgaria carefully supported the processes that led to the gradual transfer of state sovereignty from the federal center in Belgrade to the republican one in Skopje. In a response to the January 25, 1991 Declaration of Sovereignty of the SRM, the Bulgarian foreign ministry welcomed

${ }^{6}$ Амандмани на Уставот на Социјалистичка Република Македонија, 20.09.1990; Уставен закон за спроведување на амандманите LVII до LXXX на Уставот на CPM, 20.09.1990; Закон за избор и отповикување на пратеници и одборници, 21.09.1990; Закон за изборните единици за избор на пратеници во Собранието на Социјалистичка Република Македонија, 20.09.1990, in: „Службен весник на СРМ”, 21.09.1990, c. 505-524.

${ }^{7}$ The text of the 2 December 1991 letters in: Д. Малески. Бебето од катран: Македонија во мегународните односи (1991-1993). Скопје: Култура, 2012, с. 168-170; On it also: G-H. Ahrens. Diplomacy on the Edge: Containment of Ethnic Conflict and the Minorities Working Group of the Conferences on Yugoslavia. Washington, DC: Woodrow Wilson Center Press, 2007, pp. 392-393. The letters were followed by the Declaration for International Recognition of RM as Sovereign and Independent State by the parliament of RM on Dec. 19, 1991. Its text in: Службен весник на РМ, 24.12.1991, с. 901. 
that document and declared in late February 1992 that it would recognize the independence of its new neighbor in case of the breakdown of the talks between different sovereign Yugoslav republics as envisaged in the SRM's declaration ${ }^{8}$.

In mid-September 1991, just after the RM's Referendum on Sovereignty, Greece initiated a trilateral Greek-Bulgarian-Serbian summit in order to control and prevent the independence of the emerging new country. Bulgarian president Zhelyu Zhelev resolutely opposed that proposal and advanced the participation of the Republic of Macedonia as well as a precondition for such a summit. He also formulated the general principles of Bulgaria's policy to the Yugoslav crisis: the country will not try to make use of the internal difficulties of Yugoslavia, it will not interfere in its internal affairs, it recognizes the right of self-determination to the Yugoslav republics up to the level of independence. This led to the failure of the projected summit in Athens. Instead Sofia received the prime minister of RM Nikola Kljusev on a first quasi-state visit ${ }^{9}$.

As is well known, Bulgaria was the first country to recognize the independence of its new neighbor on January 15, 1992, hours after the publication of the report of the Robert Badinter's expert commission in Skopje's favor. The new country was acknowledged under its only existing official designation of the time - the constitutional name - the Republic of Macedonia. In the following weeks and months Bulgaria tried to promote the independence internationally. At that time it had no particular influence over the 12-member club of the European Community, but Sofia lobbied other countries like Turkey and especially Russia. President Boris Yeltsin recognized RM after talks with Zhelev on his flight back from Sofia to Moscow on August 4, $1992^{10}$.

In February 1994 Greece imposed a trade blockade on its northern neighbor. In the conditions of the UN embargo over Serbia (Federal Republic of Yugoslavia) this cut off the new state from its main outlet to the world market - the Salonika port. Through its Black sea ports Bulgaria immediately provided life support to RM's economy and propped up its sustainability.

Later on during the critical months of the Kosovo war in 1999 Sofia provided diplomatic support to Skopje and equipped and financed important refugee camp and field hospital in Radusha, near the Kosovo border. At its height in May 1999 according to some estimates it accommodated nearly 7500 refugees ${ }^{11}$. Bulgaria provided some military technical aid (nearly 100 tanks and howitzers) in 1999 and further ammunition in March 2001 to the young Army of the Republic of Macedonia ${ }^{12}$ which was an important asset during the 2001 ethnic conflict.

8 Декларација за сувереност на Социалистическа република Македонија, in: „Службен весник на CPM", 01.02.1991, c. 45; Declaration of the Ministry of Foreign Affairs of Bulgaria, Feb. 1991, in: Bulgaria recognizes SR Macedonia's sovereignty, 'Macedonian Tribune', May 16, 1991, p.1.

${ }^{9} \mathrm{Zh}$. Zhelev, In at the deep end. The Bulgarian Presidency in Times of Political Change. Sofia: Trud Publishing House, 2008, p. 148; Б. Банчев. Краят на гръико-българското геополитическо партньорство (несъстоялата се гръико-българо-сръбска срещза през септември 1991 г.), Геополитика, 2005, №3, с. 39-47.

${ }^{10} \mathrm{Zh}$. Zhelev, In at the deep end..., p. 157-161; Е. Колосков. Страна без названия: внешнеполитический аспект становления македонского госсударства (1991-2001). Москва: Институт славяноведения РАН, 2013, c. 159-164.

${ }^{11}$ D. Donev, S. Ončeva, I. Gligorov. Refugee Crisis in Macedonia during the Kosovo Conflict in 1999, Croatian Medical Journal, 43 (2002), No. 2, 185.

${ }^{12}$ И. Костов. Свидетелства за прехода. 1989-1999. София: Сиела, 2019, с. 375-377. 


\section{Countering and dismantling of Macedonianism as provocative construct of history and as RM's foreign policy practice.}

The ideology of Macedonianism (or Macedonism), both in its 'Yugoslav' and 'antiquated' versions, pretending for the existence of separate Macedonian ethnicity well before the second quarter of the twentieth century, not only distorted and violated basic tenets of the cultural and state heritage of Bulgarian and other peoples in the region but also continued as a form of aggressive foreign policy practice of claiming ethnic Macedonian minorities in Bulgaria, Greece and other neighboring countries. This policy was instituted by Tito's Yugoslavia and maintained by the newly independent republic. It was explicitly written in the new constitution of RM adopted on November 17, 1991 in its article 49: "The Republic cares for the status and rights of those persons belonging to the Macedonian people in neighboring countries, as well as Macedonian expatriates, assists their cultural development and promotes links with them"13.

Bulgaria tackled this problem in two ways. Firstly, as a result of its persistent diplomatic action on February 22, 1999 a bilateral Declaration of the two prime ministers was signed where "the Republic of Macedonia hereby declares that nothing in its Constitution can or should be interpreted as constituting, now or whenever in the future, a basis for interference in the internal affairs of the Republic of Bulgaria for the purpose of defending the status and the rights of persons who are not citizens of the Republic of Macedonia"14. This text was confirmed in 2008 and again included in the bilateral Treaty of Friendship, Good-Neighborliness and Cooperation signed on August 1, $2017^{15}$.

Secondly, starting with the cabinet of Ljubcho Georgievski Bulgaria accomplished joint official commemorations with RM of key common historical figures of the two countries like that of sts. Cyril and Methodius on May 24, 1999 in Rome. Later, similar ceremonies were held with President Boris Traykovski. Even President Branko Tsrvenkovski together with his Bulgarian counterpart Georgi Parvanov took part in the ceremony of laying flowers at the memorial of early twentieth century revolutionary Yane Sandanski in Melnik, Bulgaria on March 5, 2008 ${ }^{16}$. These practices had to confirm the common history of the two states and to overcome the arbitrary constructs of Macedonianism.

These policies reached its height during the short premiership of Vlado Buchkovski (Dec. 2004 - August 2006). However, in early June 2006 an attack against his proposals for the joint celebration of the historical events, especially the Ilinden uprising, was orchestrated by President Branko Tsrvenkovski, the entrenched historical and media establishment and opposition leader Nikola Gruevski ${ }^{17}$. During the subsequent rule of Gruevski's

\footnotetext{
${ }^{13}$ Constitution of the Republic of North Macedonia, https://www.sobranie.mk/the-constitution-of-the-republicof-macedonia-ns_article-constitution-of-the-republic-of-north-macedonia.nspx (accessed on April 19, 2020).

${ }^{14}$ Joint declaration of the Prime Minister of the Republic of Bulgaria and of the Prime Minister of the Republic of Macedonia, Feb. 22, 1999, in: L. Ivanov et al. Bulgarian policies on the Republic of Macedonia, Sofia: Manfred Worner Foundation, 2008, p. 73-75.

${ }^{15}$ Договор за приятелство, добросъседство и сътрудничество между Република България и Република Македония, Дьржавен вестник, 2018, бр. 19 (02.03.2018), с. 16-18.

${ }^{16}$ Македония с ангажимент към българите, информационна агенция Фокус, 06.03.2008, http://www. focus-news.net/scandal/0000/00/00/1822/ (accessed on 20.04.2020).

${ }^{17}$ Б. Горгески. По идејата за македонско-бугарски празнувања: Илинден падна на Илинденска бб.; К. Блажевска. Премиер од Илиенци, „Дневник”, 06.06.2006.
} 
VMRO-DPMNE dominated cabinets (August 2006 - May 2017) Skopje withdrew from joint commemoration practices and officially endorsed the project of antiquation, i.e. of antiquated Macedonianism, of drawing direct links with the ancient Macedonia and Makedones. That led to the exacerbation of the RM's relations with Bulgaria and Greece and to the long halt of its EU integration process.

After the downfall of the Gruevski's regime one of the first acts of the new prime minister Zoran Zaev was to visit Sofia and to lay flowers together with his Bulgarian counterpart Boyko Borisov to the monument of medieval Bulgarian Tsar Samuel on June 20, 2017. They sped up the negotiations and on August 1, 2017 (on the eve of the Ilinden uprising anniversary) signed the Treaty of Friendship, Good-Neighborliness and Cooperation in Skopje. It stressed "the common history that connects the two countries and their peoples" and postulated that the two states will organize "joint celebrations of the common historical events and personalities". To this end, the treaty established the Joint multidisciplinary expert commission on historical and educational issues "to contribute to the objective, based on authentic and based on proofs of historical sources for scientific explanation of historical events"18. Thus the concept of "common history" of the two countries was officially and legally recognized and a special bilateral state body for its implementation was institutionalized.

The treaty entered into force in February 2018 and the first meeting of the Joint Commission was held in early July 2018. In its further statements Bulgaria was adamant that its attitude to the neighbor, including its support in the EU accession process would depend on the implementation of the treaty and more specifically on the progress of the work of the Joint historical commission ${ }^{19}$.

\section{Seeking of solutions within a wider EU and NATO framework; support for the Republic of /North/ Macedonia's integration into NATO and EU structures.}

After the initial recognition of January 15, 1992 Bulgaria was very slow to establish full diplomatic relations with RM. In August 1992 it decided to open only a Consulate General in Skopje ${ }^{20}$. One of the reasons for this delay was the wish of Sofia to harmonize its policies with those of larger European and Euroatlantic community. Therefore only after the prolonged and complicated accession of the RM into the UN and its recognition by the major European states the formal diplomatic relations were established as late as December 21, 1993. This attitude outlined the third general feature of the Bulgarian approach to RM: seeking of solutions within wider European and Euroatlantic framework.

This principle was especially important in the dramatic months of the Kosovo war in 1999. Both states were overwhelmed by the conflict on their borders. They previously

\footnotetext{
${ }^{18}$ Договор за приятелство..., с. 16-17.

${ }^{19}$ Рамкова позиция [на Република България] относно разширяване на ЕС и процеса на стабилизиране и асоцииране: Република Северна Македония и Албания, 09.10.2019, https://www.gov.bg/bg/prestsentar/ novini/ramkova-pozitsia (accessed on 20.04.2020).

${ }^{20}$ А. Димитров. Раждането на една нова държава. Република Македония между югославизма и наиионализма. София: АИ „Проф. М. Дринов”, 2011, с. 173.
} 
cooperated with NATO and both declared their wish for full membership in the alliance: the Republic of Macedonia in December $1993^{21}$ and Bulgaria in early $1997^{22}$. However, now the two governments had to make hard choices overcoming obstruction from the opposition, the strong meddling in internal affairs from the neighboring FR of Yugoslavia and the war fears of the wider public. The cabinets made these difficult decisions against these odds: Ivan Kostov's government committed Bulgaria to the Alliance policy by imposing economic sanctions on the FRY in accordance with its EU associate members' obligations, by urging Belgrade to accept the international community's conditions, and crucially, by opening its airspace to NATO flights. In mid-June 1999 it refused the Russian military request for military flights thus preventing beefing up the Russian military unit at the Pristina airport and the creation of the Russian sector in Kosovo. Meanwhile Ljubcho Georgievski's government opened up its territory to NATO air forces and land troops and accommodated over 300,000 refugees from Kosovo with international help. The two neighboring countries closely cooperated: for example, in the height of the internal mass protests over the opening of the national airspace to NATO. Deputy prime minister of RM Dosta Dimovska spoke at a large pro-government and pro-NATO meeting in Sofia on April 27, $1999^{23}$. On the other hand, as has already been mentioned, Bulgaria provided diplomatic support, financial assistance of 100 million leva (=DM), and operational organization of the big camp and field hospital for the Kosovo refugees in RM.

Due to a variety of factors Bulgaria accomplished its NATO and EU accession respectively in April 2004 and January 2007 while the Republic of Macedonia was still lagging far behind Croatia, Montenegro and in terms of NATO - even of Albania. As a member of the two institutions Bulgaria provided continuous support for the fulfillment of the required criteria for RM's integration in the two international organizations. Sofia's role was especially adamant in the first half of 2018 when it had the rotating presidency of EU. Bulgaria once again managed to return the Western Balkans on the EU agenda through a set of initiatives that culminated with the Sofia Declaration of the EU in May 2018 ${ }^{24}$. The Bulgarian presidency contributed to the favorable context that led to the groundbreaking Prespa Agreement between Athens and Skopje in mid-June 2018. The end of the presidency was marked by the EU council conclusions setting out the path towards opening accession negotiations with RM in June $2019^{25}$ - a realistic date bearing the complicated timetables required for the constitutional changes and ratifications stemming out of the Prespa Agreement in mind.

${ }^{21}$ Одлука за стапување на РМ во членство во Северно-атлантската договорна организација - НАТО, 23.12.1993. in: „Службен весник на РМ”, 27.12.1993, с.1867. On subsequest cooperation with NATO: Address by H.E. Dr. Ljubomir Frchkoski, Minister for Foreign Affairs of the Republic of Macedonia at the Acceptance Ceremony for the Individual Partnership Programme between the Republic of Macedonia and NATO for 19961998, June 12, 1996, https://www.nato.int/cps/en/natohq/opinions_25163.htm?selectedLocale=en (accessed 4/20/2020).

${ }^{22}$ B. Tashev. In Search of Security: Bulgaria's Security in Transition, in: Lansford, T and B. Tashev (eds.). Old Europe, New Europe and the US: Renegotiating Transatlantic Security in the post 9/11 Era. Burlington, VT: Ashgate, 2005, pp. 132-135.

${ }^{23}$ Костов, И. Свидетелства за прехода..., с.370.

${ }^{24}$ Sofia Declaration of the EU - Western Balkans Summit, May 17, 2018, https://www.consilium.europa. eu/media/34776/sofia-declaration_en.pdf (accessed 4/20/2020).

${ }^{25}$ Council conclusions on enlargement and stabilization and association process, June 26, 2018, p. 16, https://data.consilium.europa.eu/doc/document/ST-10555-2018-INIT/en/pdf (accessed 4/20/2020). 
Bulgaria was not direct party to the Athens-Skopje negotiations on the name issue of the former Yugoslav republic ongoing under UN auspices after 1993-1995. However, it had signaled as early as in June 2011 that a name with geographical qualifiers might cause objections in Bulgaria because Pirin Macedonia, a section of Bulgaria, geographically is part of 'North', or 'Upper' Macedonia ${ }^{26}$. These reserves were repeated in the years and months leading to the agreement on the name issue. Nevertheless, willing to contribute to the stabilization of the region, to the NATO- and EU-integration of its neighbor and of the Western Balkans, Bulgaria accepted the Prespa Agreement in general, including the new agreed name. After the agreement entered into force on February 14, 2019 Bulgaria recognized the new full official of its neighbor - the Republic of North Macedonia (RNM). Bulgaria required only assurances from Skopje that the new name refers to the state entity and not the geographical region of North Macedonia that also encompasses parts of Bulgaria $^{27}$, i.e. Pirin (North-Eastern) Macedonia, or the Blagoevgrad region. Despite some still continuing misgivings in bilateral relations, Bulgaria unconditionally ratified the NATO-accession protocol with North Macedonia on February 20, 2019 - the fourth member country to do so after Greece, Slovenia and Albania. This eventually led to the completion of the RNM's accession process on March 27, 2020.

The Bulgarian support for NATO- and especially EU-integration of the Republic of (North) Macedonia was continuous and adapted to the general EU principle of conditionality. In order to accommodate bilateral relations within the larger EU accession framework Bulgaria as early as in 2008 proposed signing a treaty for good-neighborliness. Some negotiations started but soon it became clear the Gruevski's government was unwilling to accept some important clauses, including the key notion of the 'common history' of the two countries. This coincided with the vigorous propagation of the antiquated Macedonianism and to the general slide of RM's policies. Therefore starting from 2012 Bulgaria tied its support to RM's EU prospects with the signing of the bilateral treaty for good-neighborliness.

As already noted, after the fall of VMRO-DPMNE government, bilateral negotiations were accelerated, leading to the signing of the Treaty of Friendship, Good-neighborliness and Cooperation on August 1, 2017 in Skopje. This agreement and the favorable wider international context triggered the intensification of the negotiations between prime ministers Zoran Zaev and Andreas Tsipras and their foreign ministers that led to the Prespa Agreement of June 17, 2018. From the perspective of Sofia, it is important that the bilateral good-neighborliness treaty with Skopje was acknowledged, along with the Prespa Agreement, by all interested parties as the cornerstone that permitted the further NATO and EU- accession progress of the Republic of North Macedonia.

To sum up, 1989 did indeed change a lot both for Bulgaria and Vardar Macedonia and ushered a new period in their mutual relations. Even the often overlooked events in Skopje, the little-noticed congress of the local League of Communists of Macedonia in late November 1989 also contributed to the dismantling of some small bricks out of the pan-

${ }^{26}$ Bulgarian president Georgi Parvanov's answers to journalist questions during his state visit in Slovenia on 6 June 2011: България е против името “Северна Македония”, „Сега”, 6/6/2011, http://old.segabg.com/article. php?sid=2011060600090000164 (accessed 4/20/2020); Софија ги откри картите. Бугарија фаќа позиции за името, „Дневник”, 6/7/2011.

${ }^{27}$ Рамкова позиция... 
-European Berlin Wall. Otherwise, what is today the newest NATO-member - the Republic of North Macedonia, might have been quite longer and firmer within the Miloševićgoverned policy, or in the still existing somewhat grey zones in the post-Yugoslav space.

In the years after 1989 Bulgaria's approach stuck to the three key constant aforementioned principles: support for the independence and for the statehood of the new Republic of Macedonia; countering and dismantling of Macedonianism both as provocative construct of history and as Skopje's foreign policy practice; seeking of solutions within wider EU and NATO framework and support for Republic of /North/ Macedonia's integration into NATO and EU structures. While these guidelines were in general harmony, it has not always been easy to pursue all of them. Nevertheless, it seems that Bulgarian diplomacy tried and tries to balance and apply a combination of all of them.

On March 25, 2020 the EU Council with the active participation of Bulgaria accomplished another act in this direction: it decided to open negotiations with the Republic of North Macedonia and Albania but set no specific date for adoption of negotiation framework and for convening the intergovernmental conference to start the negotiation process with the two countries. The conclusion stressed that 'good neighborly relations and regional cooperation remain essential elements of the enlargement process' and noted 'the importance of achieving tangible results and implementing in good faith bilateral agreements, including the Prespa Agreement with Greece and the Treaty on Good Neighborly Relations with Bulgaria as part of the enlargement process ${ }^{28}$. All in all, the balancing of the three aforementioned principles is still an ongoing process and how it will evolve remains to be seen.

\section{Bibliography}

Published primary sources

Documents

Address by H.E. Dr. Ljubomir Frchkoski, Minister for Foreign Affairs of the Republic of Macedonia at the Acceptance Ceremony for the Individual Partnership Programme between the Republic of Macedonia and NATO for 1996-1998, June 12, 1996, https://www.nato.int/cps/en/natohq/ opinions_25163.htm?selectedLocale=en (accessed on 4/20/2020).

Constitution of the Republic of North Macedonia, https://www.sobranie.mk/the-constitution-of-therepublic-of-macedonia-ns_article-constitution-of-the-republic-of-north-macedonia.nspx (accessed on April 19, 2020).

Council conclusions on enlargement and stabilization and association process, June 26, 2018, p. 16, https://data.consilium.europa.eu/doc/document/ST-10555-2018-INIT/en/pdf (accessed on 4/20/2020).

Council conclusions on enlargement and stabilization and association process: the Republic of North Macedonia and the Republic of Albania, 25 March 2020, p. 2. https://data.consilium.europa. $\mathrm{eu} / \mathrm{doc} /$ document/ST-7002-2020-INIT/en/pdf (accessed on 20.04.2020).

\footnotetext{
${ }^{28}$ Council conclusions on enlargement and stabilization and association process: the Republic of North Macedonia and the Republic of Albania, March 25, 2020, p. 2. https://data.consilium.europa.eu/doc/document/ST7002-2020-INIT/en/pdf (accessed 4/20/2020).
} 
Declaration of the Ministry of Foreign Affairs of Bulgaria, Feb. 1991, in: Bulgaria recognizes SR Macedonia's sovereignty, 'Macedonian Tribune', May 16, 1991, p. 1.

Joint declaration of the Prime Minister of the Republic of Bulgaria and of the Prime Minister of the Republic of Macedonia, Feb. 22, 1999, in: L. Ivanov et al. Bulgarian policies on the Republic of Macedonia, Sofia: Manfred Worner Foundation, 2008, p. 73-75.

Sofia Declaration of the EU - Western Balkans Summit, 17 May 2018, https:/www.consilium.europa.eu/media/34776/sofia-declaration_en.pdf (accessed on 4/20/2020).

Амандмани на Уставот на Социјалистичка Република Македонија, 9/20/1990; Уставен закон за спроведување на амандманите LVII до LXXX на Уставот на CPM, 9/20/1990; Закон за избор и отповикување на пратеници и одборници, 9/21/1990; Закон за изборните единици за избор на пратеници во Собранието на Социјалистичка Република Македонија, 9/20/1990, in: „Службен весник на СРМ”,9/21/1990, с. 505-524.

Декларација за меѓународно признавање на Република Македонија како суверена и независна држава, in: „Службен весник на РМ”, 12/24/1991, с. 901.

Декларација за сувереност на Социалистическа република Македонија, in: „Службен весник на СРМ", 2/1/1991, с. 45.

Договор за приятелство, добросъседство и сътрудничество между Република България и Република Македония, in: „Дьржавен вестник”, 2018, бр. 19 (3/2/2018), с. 16-18.

Закон за изменување и дополнување на Законот за општествените организации и здруженијата на граѓани, in: „Службен весник на СРМ”, 4/13/1990, с. 237-239

Одлука за стапување на РМ во членство во Северно-атлантската договорна организација НАТО, 12/23/1993, in: „Службен весник на РМ”, 12/27/1993, с.1867.

Рамкова позиция [на Република България] относно разширяване на ЕС и процеса на стабилизиране и асоцииране: Република Северна Македония и Албания, 10/9/2019, https://www.gov.bg/bg/prestsentar/novini/ramkova-pozitsia (accessed on 4/20/2020).

Media articles

България е против името „Северна Македония”, „Сега”, 6/6/2011, http://old.segabg.com/article. php?sid=2011060600090000164 (accessed 4/20/2020).

Блажевска, К. Премиер од Илиенци, „Дневник”, 6/6/2006.

Горгески, Б. По идејата за македонско-бугарски празнувања: Илинден падна на Илинденска бб., „Дневник”, 6/6/2006.

Македония с ангажимент към българите, информационна агенция Фокус, 3/6/2008, http://www. focus-news.net/scandal/0000/00/00/1822/ (accessed on 4/20/2020).

Софија ги откри картите. Бугарија фаќа позиции за името, „Дневник”, 6/7/2011.

Memoirs

Ahrens, G-H. Diplomacy on the Edge: Containment of Ethnic Conflict and the Minorities Working Group of the Conferences on Yugoslavia. Washington, DC: Woodrow Wilson Center Press, 2007.

Zhelev, Zh. In at the deep end. The Bulgarian Presidency in Times of Political Change. Sofia: Trud Publishing House, 2008.

Йорданов, Г. Притаени мигове. Книга втора. Откровения. София: Издателство „Захарий Стоянов", 2017.

Костов, И. Свидетелства за прехода. 1989-1999. София: Сиела, 2019.

Малески, Д. Бебето од катран: Македонија во мегуннародните односи (1991-1993). Скопје: Култура, 2012.

Орданоски, С. Пресудни години: разговор со д-р Јаков Лазароски: Македонија 1986-1989. Скопје: Култура, 2013. 
Monographs

Димитров, А. Раждането на една нова държава. Република Македония между югославизма и наиионализма. София: АИ „Проф. М. Дринов”, 2011.

Колосков, Е. Страна без названия: внешнеполитический аспект становления македонского госсударства (1991-2001). Москва: Институт славяноведения РАН, 2013.

Мојаноски, Ц. Летопис на македонската демократија. Скопје: Пакунг, 2013.

Articles

Donev, D., S. Ončeva, I. Gligorov. Refugee Crisis in Macedonia during the Kosovo Conflict in 1999, Croatian Medical Journal, 43(2002), No. 2, pp.184-189.

Tashev, B. In Search of Security: Bulgaria's Security in Transition, in: Lansford, T and B. Tashev (eds.). Old Europe, New Europe and the US: Renegotiating Transatlantic Security in the post 9/11 Era. Burlington, VT: Ashgate, 2005, pp. 127-150.

Банчев, Б. Краят на гръико-българското геополитическо партньорство (несъстоялата се гръико-българо-сръбска среща през септември 1991 г.), Геополитика, 2005, №3, с. 39-47.

Спасеноски, А. Еволуичја на македонскиот партиски систем от монизам кон плурализам. Политичка мисла, бр. 58, декември 2019, с. 21-42.

Naoum Kaytchev jest profesorem nowożytnej i współczesnej historii Bałkanów na Uniwersytecie „St. Kliment Ohridski” w Sofii. Pełnił funkcję Konsula Generalnego Bułgarii w Toronto (19992000) oraz w Bitoli w Macedonii Północnej (2007-2010). Od roku 2018 jest wiceprzewodniczącym multidyscyplinarnej komisji eksperckiej badającej problemy historyczne i edukacyjne w Bułgarii i Macedonii Północnej. Jego główne zainteresowania badawcze dotyczą późnonowożytnej i współczesnej historii Macedonii oraz intelektualnej i społecznej historii Chorwacji, Serbii i Bułgarii w XIX wieku. Szczególną uwagę poświęca problemowi budowania narodu i nacjonalizmu. Jest autorem m.in. publikacji Macedonia upragniona: armia, szkolnictwo i budowanie narodu w Serbii i Butgarii, 1878-1912, Sofia, 2003 (w języku bułgarskim) oraz monografii Maski w dót! Nacjonalizm na Batkanach w XX wieku, Sofia, 2018 (w języku bułgarskim, współautorstwo). 